\title{
Editorial
}

\section{Strategic developments in financial services marketing}

Journal of Financial Services Marketing (2008) 13, 1-4. doi:10.1057/fsm.2008.8

\section{INTRODUCTION}

The recent trends, challenges and developments that we observe in the banking sector, and are taken into consideration in order to define the basic elements of strategic analysis of banks, include the following:

(1) Electronic technology has changed the way financial products are produced and delivered, and has offered alternatives to physical contact, facilitating client participation, which increases customer convenience and decreases costs.

(2) Value-added services are acting against commoditisation of services and the resulting limitation of competitive strategies in pricing.

(3) The development of bankassurance has given financial organisations the opportunity to crosssell insurance products through the distribution channels of banks and banking products through the distribution channels of insurance companies, increasing the effectiveness of sales personnel and the efficiency of both.

(4) Lower profitability of the core product, market saturation, rising operating costs, narrow lending spreads and increased competition forced financial institutions to reshape their marketing strategies in order to increase their competitiveness.

Following deregulation and the rapid electronic technology revolution, banks have aimed to increase their competitiveness through cost reduction and quality improvement. Cost reduction has been obtained through mergers and acquisitions leading to increased economies of scale and economies of scope, by increasing productivity, by reengineering and by reducing production and distribution costs through e-banking.

Better quality leads to differentiation of the bank from its competitors, increases cross-selling, improves the bank's image and consequently employee morale, motivation and satisfaction, leading to improved performance and satisfied customers. In the current climate, financial services customers are more demanding of quality issues.

Today's customers possess a higher standard of living and are better educated than in the past. They are more informed, need fast and convenient service due to limited time availability and are influenced much more by the pricing policies of financial institutions than in the past because many customers find the differences among competitive products to be few and insignificant and tend to be less loyal to a specific bank. Set against this backdrop, the marketing strategies of financial institutions are becoming more sophisticated.

A proactive strategy, aimed at improving marketing performance, must have a focus in service quality, customer satisfaction and customer loyalty, which can reduce price elasticity. Banks could build effective marketing strategies to increase their customers' loyalty if they study their behaviour systematically: to understand the major dimensions of customer satisfaction, to assess the existing gap between customer expectations and the services offered and to identify their advantages and disadvantages vis-à-vis the competition. Current developments require financial institutions to 
redefine their strategic scope from transactional to relationship banking, in order to gain long-term customer relationships and increase customer loyalty.

\section{THE INTERNATIONAL CONFERENCE: 'STRATEGIC DEVELOPMENTS IN SERVICES MARKETING'}

Major changes over the last 30 years have underlined the increasing importance of the service sector, for both developed and developing economies throughout the world. As a result, service industries have become increasingly competitive, motivating managers to seek differentiation and competitive advantage through the application of contemporary marketing practices. The marketing academic community, responding to such a need, has recently escalated its research efforts, thus making services one of the most important areas of its interest.

This special issue aims to present some important themes of trends, challenges and strategic developments in financial services marketing. Papers of the special issue have been selected from among the high quality papers presented during the First Biannual International Conference in Services Marketing titled: 'Strategic developments in services marketing'. The Conference was organised jointly by the Department of Business Administration of the University of the Aegean, Greece and the University of Glasgow, Scotland, in cooperation with the Greek Marketing Academy, and took place between 27th and 29th of September 2007 in Chios Island, Greece.

Eighty-nine papers were submitted to the Conference, which were reviewed by 18 Greek and foreign reviewers; 60 papers were accepted for the main Conference and eight for the Doctoral Colloquium. The academic programme of the Conference consisted of 18 separate sessions and two working paper sessions, one panel session with journal editors, one special session with presentations of case studies from service companies about planning and implementing marketing strategies and one roundtable discussion of top academics with top practitioners.

Two distinguished members of the international academic community took part: Professor Luiz Moutinho, Professor of Marketing at the University of Glasgow and co-organiser of the Conference and Professor Enrique Bigne, Professor of Marketing and Market Research at the University of Valencia, Spain, of which he is Vice Chancellor since 2006.

\section{PAPERS INCLUDED IN THIS SPECIAL ISSUE}

Authors of selected papers presented at the Conference were asked to further improve their manuscripts and subsequently resubmit them for reviewing and publication consideration in this special issue of the Journal of Financial Services Marketing. Seven papers were accepted for inclusion in this special issue, all of them addressing major challenges that financial institutions are facing and comprise elements of their strategies.

Two papers are focusing on alternative distribution channels. The first of these titled: 'Does trust in the bank build trust in its technology-based channels?', written by Sergios Dimitriadis and Nikolaos Kyrezis, investigates the construct of trust and its antecedents in the context of technologybased distribution channels. Specifically, it tests the role of affective and cognitive trust in the bank in building trust in these channels. The affective component of trust in the bank proved to be the most important predictor of trust, especially in the phone and internet channel, and seems to form, in particular, the affective trust in these channels. The cognitive component of trust in the bank is transferred only in the case of ATM's trust. Findings provide useful managerial implications suggesting that bank managers should build the affective trust through transparency, fairness, keeping promises, adapting their services to the needs of 
customers, establishing policies that create for the customer a sense of security and a sense of nonexploitation. Other means such as information, communication or demonstrations should be used to develop cognitive trust beliefs in the channel (in terms of speed, effectiveness, problem solving, consistent attitude and consistence at procedures).

The second paper focusing on distribution channels titled: 'Using the extended innovation attributes framework and consumer personal characteristics as predictors of internet banking adoption', written by Spiros Gounaris and Christos Coritos, investigates the interplay between utilitarian aspects of banking activity (usefulness and ease of use) and social and psychological aspects of adoption of a technologically based distribution channel for financial services. It aims to provide a framework of innovation attributes that will offer a more comprehensive understanding of the factors forming consumers' decisions to adopt internet banking and to compare the ability of these factors, as well as other important ones (demographics and psychographics) in predicting future adoption of internet banking. The results of their study showed that apart from the usability (relative advantage and ease of use), social (image and result demonstrability) as well as psychological (trialability) aspects of technology adoption by consumers play a significant role.

Two papers investigate how several customer satisfaction aspects influence consumer behaviour in financial services. The first of these papers titled: 'Factors that affect consumers' cross-buying intention: A model for financial services', written by Magdalini Soureli, Barbara Lewis and Kalipso Karantinou, tests a model of factors that affect customers' intentions of cross-buying retail financial services. Their study relates to the development of a new research model, comprising four key variables: two variables relating to the expectations or anticipation for the future delivery which refer to the bank's image and trust in the bank and two variables relating to the past history of the relationship with the bank, such as satisfaction and perceived value that interrelate with each other and affect either directly or indirectly cross-buying intention. As managerial implications, they conclude that customers may intend to buy more from their bank when they trust it and think highly of it, but only if this is accompanied by customer satisfaction with that bank, which is affected by the value that customers perceive that the bank offers.

The other paper titled: 'Price satisfaction and personnel efficiency as antecedents of overall satisfaction from consumer credit products and positive word of mouth', written by Constantine Lymperopoulos and Ioannis Chaniotakis, investigates the relationship between overall customer satisfaction, personnel efficiency (the human factor of service), price satisfaction (pricequality ratio, relative price, price confidence, price transparency, price reliability and price fairness) and word of mouth. Data analysis suggests that if a bank wants to benefit from positive word of mouth and the related outcomes (increased customer loyalty and attraction of new customers), there is a need to place special emphasis on increasing customers' perceived price satisfaction as well as overall satisfaction. Consequently personnel efficiency is very important, because it affects both of these variables. Findings provide useful theoretical and managerial implications.

The article titled: 'Variables influencing the customer relationship management of banks', written by Chantal Rootman and Johan Bosch, investigates the influence of banking employees on the Customer Relationship Management of banks. The empirical results indicated positive relationships between perceived attitude and perceived knowledgeability and the effectiveness of CRM strategies. Bank employees, who directly interact with banking clients should be knowledgeable regarding bank matters and 
should display positive attitudes towards their working environment because they play a vital role in the effectiveness of a bank's CRM strategies. Useful managerial implications regarding recommendations concerning bank employee knowledgeability and attitude are discussed.

The article titled: 'A two stage dynamic credit scoring model. Based on customer's profile and time horizon', written by Maria Mavri, Vasilis Angelis, George Ioannou, Eleni Gaki and Iason Koufodontis, concerns a twostage dynamic credit scoring model that estimates the risk level of a credit card applicant, as well as the probability of default. The proposed model, which may prove to be a valuable tool for the Credit Card Approval Department of a bank, evaluates the financial credibility of all applicants and predicts repayment behaviour for those who have been characterised as creditworthy customers. Factors such as the applicants' monthly income, age, owned property and financial credibility up to date determine the risk level, while the survival time of those applicants who have been classified as credible depends on income and age.

The final paper in the special issue titled: 'Are men better investors than women? Gender differences in mutual fund and pension investments', written by Rita Martenson, reviews prior studies on gender differences for financial consumers, analyses how the Swedish population has allocated their pension investments within the state pension system, as well as the results from a nationally representative sample of consumers. The analysis of the sample showed that in comparison with women, men feel more certain about their decisions, are more involved in the stock market, own longer mutual funds, are willing to take higher risks, monitor the stock market more frequently, have higher subjective knowledge of the stock market, think that it is less difficult to use information about the stock market, make more of their own evaluations of the stock market, have more knowledge to interpret annual reports and are more profit-oriented.

\section{CONCLUSION}

To conclude, we cannot of course claim that this special issue covers all trends, challenges and strategic developments in financial services marketing, because this goes beyond the scope of any Journal special issue. Besides, bank marketing strategies have to meet the challenges of a constantly changing environment, which banks have to study carefully.

However, following Plato's (Laws) thinking: 'As craftsmen say, even the largest stones need smaller stones to support them', we hope that we will contribute with the 'small mental stones' of this special issue to the academic dialogue about contemporary scientific problems of our field.

Constantine Lymperopoulos Guest Editor 